\title{
Immunoglobulin heavy chain constant region variants in rheumatoid arthritis
}

\author{
M G LOFTUS, P SANDERS, G DE LANGE, AND D M GRENNAN
}

From the University of Manchester, Rheumatic Diseases Centre, Hope Hospital, Salford, and the๊ Immunogenetics Laboratory, Red Cross Blood Transfusion Service Amsterdam

SUMMARY Polymorphisms within the immunoglobulin heavy chain constant region at switch (S) $\mu$ and $\mathrm{S} \alpha 1$ loci were studied in patients with rheumatoid arthritis (RA) and controls in parallel with? $\mathrm{Gm}$ and $\mathrm{A} 2 \mathrm{~m}$ allotyping. $\mathrm{S} \mu$ and $\mathrm{S} \alpha 1$ restriction fragment length polymorphisms were defined ${ }^{\oplus}$ using a $S \mu$ probe which was hybridised to SstI digests of DNA extracted from circulating white $\vec{\circ}$ cells. There were no differences in $S \mu$ and $S \alpha 1$ gene or phenotype frequencies between RA and $\mathbb{\infty}^{\infty}$ control groups nor within the RA population between DR4 positive and negative subjects. The Gm allotype G1m(x), coded for by genes at the gamma-1 locus, was found in $29 / 92(32 \%)$ of DR $4 \stackrel{\text { 工 }}{\triangle}$ positive and $5 / 52(10 \%)$ of DR4 negative subjects with RA, as compared with $25 / 115(22 \%) \mathrm{cto}$ controls. The A2m allotype A2m(2), coded for by the $\alpha 2$ locus, was found in $11 / 92(12 \%)$ of DR $4 \stackrel{?}{\circ}$ positive subjects with RA, zero of 52 DR4 negative subjects, and 5/115 (4\%) of controls. These $\mathbb{\Phi}_{\mathbb{D}}$ results exclude a major effect of genes within the heavy chain constant region linked to $\mu$ or $\alpha 1_{\vec{L}}^{-}$ loci on susceptibility to RA, but suggest that further study of variants closely linked to the locus is indicated.

There is a genetic predisposition to rheumatord arthritis (RA), which from family studies appears only partly accounted for by genes within the HLA region. ${ }^{12}$ The immunoglobulin heavy chain region locus on chromosome 14 is one of several other 'candidates' which have been proposed to contribute to this susceptibility, but the results of studies of associations between RA and the immunoglobulin heavy chain allotype $\mathrm{Gm}$ have been conflicting. Most but not all studies have failed to find any independent effect of $\mathrm{Gm}$ on susceptibility to $\mathrm{RA},{ }^{34}$ whereas three studies have reported an association between a $\mathrm{G} 1 \mathrm{~m}(\mathrm{x})$ bearing phenotype and

Accepted for publication 9 February 1989.

Correspondence to Dr D M Grennan, University of Manchester, Rheumatic Diseases Centre, Clinical Sciences Building, Hope Hospital, Eccles Old Road, Salford M6 8HD
DR4 positive but not DR4 negative RA in whiteo Europid populations, ${ }^{5-7}$ but a fourth has not. ${ }^{8}$ Two further studies have reported an association with $a \vec{F}$ different $\mathrm{Gm}^{\prime}$ phenotype in a subset of RA charac-3 terised by circulating antibodies to native type II? collagen, and this effect also appeared to beco. dependent on DR status. ${ }^{910}$ As shown in Fig. 10 the immunoglobulin heavy chain constant region $\overline{-}$ includes mu, delta, gamma-3, gamma-1, pseudo-응 epsilon-1, alpha-1, pseudo-gamma, gamma-2 gamma-4, epsilon, and alpha- 2 loci, and there is linkage disequilibrium between variants coded for by genes within the two main blocks of loci from응 gamma-3 to gamma-2. Each constant region locus $>$ apart from delta is preceded by a switch locus responsible for switching class of immunoglobulin during antibody synthesis. Gm allotypes are coded

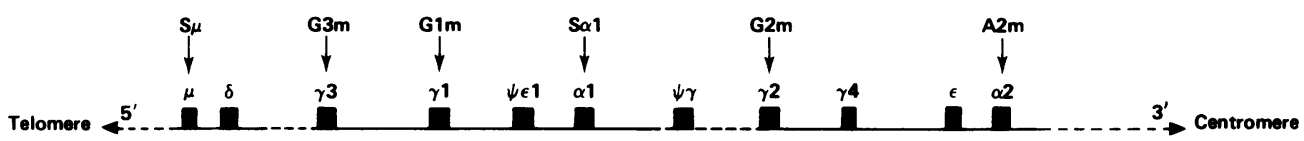

Fig. 1 Arrangement of loci in the immunoglobulin heavy chain constant region. Arrows indicate loci coding for $\mathrm{Gm}$ allotypes (G1m, G2m, G3m), A2m allotype, and for the $S \mu$ and $S \alpha l$ loci. The switch loci are immediately adjacent to the particular constant regions. The variable region is telomeric to the constant region. 
for by gamma-1, gamma-2, and gamma-3 loci and the $\mathrm{A} 2 \mathrm{~m}$ allotype carried on IgA2 molecules is coded for by the $\alpha 2$ locus. The possible effects on disease susceptibility of genes linked to other loci within the immunoglobulin heavy chain constant region may now be sought by studying restriction fragment length polymorphisms obtained with a range of DNA probes. ${ }^{11}$ In this study we have compared polymorphisms at $S \mu$ and $S \alpha 1$ loci in patients with RA and controls in parallel with the results of $\mathrm{Gm}$ and $\mathrm{A} 2 \mathrm{~m}$ allotyping.

\section{Patients and methods}

\section{PATIENTS}

Serum, DNA, or whole blood samples for subsequent DNA extraction were stored from a group of 177 unrelated subjects with classical or definite RA. ${ }^{12}$ All were white and were living in the northwest of England. DNA samples were available from 126 , serum samples for $\mathrm{Gm}$ allotyping from 144 , and both DNA and serum samples were available from 93. The resuits of $\mathrm{Gm}$ allotyping have previously been reported in 98 of the subjects with RA. ${ }^{6}$ The local control group included 135 subjects, with 115 providing samples for $\mathrm{Gm}$ allotyping, 84 providing DNA samples, and 64 providing both DNA and serum samples.

IMMUNOGLOBULIN ALLOTYPING

$\mathrm{Gm}$ and $\mathrm{A} 2 \mathrm{~m}$ allotypes were detected by haemagglutination inhibition assay of serum samples. ${ }^{13}$ The following allotypes were defined: $\operatorname{G1m}(z, a, x, f)$, G2m(n), G3m(b0, b1, b3, b5, g, c3, c5, s, t), and A2m $(1,2) .{ }^{13}$ The $A 2 m(2)$ allotype is uncommon in European populations and is found mainly in linkage disequilibrium with $\mathrm{Gm}$ haplotypes zag and zaxg.

\section{HLA TYPING}

HLA typing results were available in 108 of the subjects with RA and were used to subdivide the patients into DR4 positive and DR4 negative groups. Methods were as previously described. ${ }^{6}$

DNA STUDIES

DNA was extracted from circulating white cells and stored at $-20^{\circ} \mathrm{C}$ or $-70^{\circ} \mathrm{C}$. After digestion with SstI fragments were separated by agarose gel electrophoresis $(0.7 \%$ agarose gels, 1 volt $/ \mathrm{cm}$ for 20 hours $)$ and transferred to nylon filters (Amersham Hybond $\mathrm{N})$ by the Southern blotting technique. ${ }^{14}$ A $2 \cdot 2 \mathrm{~kb}$ $\mathrm{S} \mu$ probe was used which was derived from the phage clone H24. ${ }^{15}$ This probe cross hybridises to other switch loci and when hybridised to SstI DNA digests shows polymorphisms at both $S \mu$ and $S \alpha 1$ loci. ${ }^{11}$ The probe was radiolabelled by oligonucleotide primed synthesis. ${ }^{16}$ Filters were incubated for two hours at $65^{\circ} \mathrm{C}$ in prehybridisation solution $(6 \times$ SSC,$\quad 5 \times$ Denhardts, $200 \mu \mathrm{g} / \mathrm{ml}$ denatured salmon sperm DNA, $0.5 \%$ sodium dodecyl sulphate (SDS), followed by hybridisation solution (similar to prehybridisation solution with the addition of $10 \%$ dextran sulphate and $100 \mathrm{ng}$ of denatured probe DNA). Filters were hybridised for $16-20$ hours at $65^{\circ} \mathrm{C}$. Filters were washed at $65^{\circ} \mathrm{C}$ in $2 \times \mathrm{SSC} / 0 \cdot 1 \%$ SDS followed by $0 \cdot 2 \times \mathrm{SSC} / 0 \cdot 1 \%$ SDS .

Polymorphic bands at $7 \cdot 4,6 \cdot 9,6 \cdot 8,7 \cdot 1$, and $7 \cdot 0$ kilobases were detected at the S $\alpha 1$ locus and polymorphic bands of $2 \cdot 7,2 \cdot 2,2 \cdot 6$, and $2 \cdot 75$ kilobases at the $S \mu$ locus (Fig. 2). Accurate assignment of bands at the $S \alpha 1$ locus proved to be difficult initially because of the 100 base pairs difference between each of four variants. This problem was overcome where appropriate by running samples at $2 \mathrm{~V} / \mathrm{cm}$ for 40 hours in $0.7 \%$ agarose with human marker DNAs of known sizes. Separation of $S \mu$ polymorphisms proved adequate with the standard electrophoretic conditions.

STATISTICAL ANALYSIS

The significance of differences in phenotype and allotype frequencies was analysed by $\chi^{2}$ or Fisher's

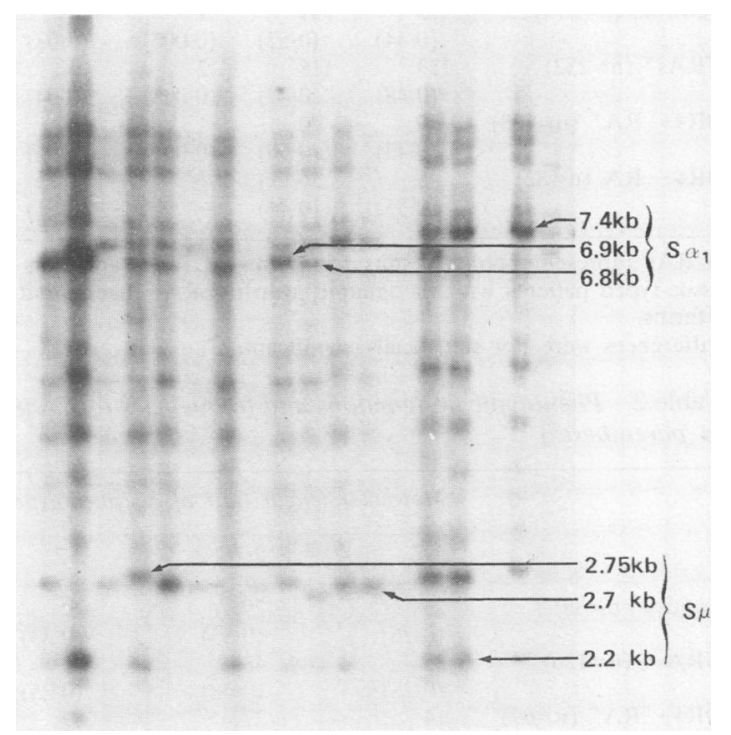

Fig. 2 Autoradiograph after hybridisation of $S \mu$ probe to SstI digested DNA from normal subjects. Polymorphic bands at $S \mu$ and $S \alpha 1$ loci are indicated. Most other bands shown represent cross hybridisation of the probe to other switch regions. 
exact test where appropriate. The significance of linkage disequilibrium between variants at different loci was also determined by $\chi^{2}$ analysis. ${ }^{17}$

\section{Results}

Tables 1 and 2 show the gene and phenotype frequencies at the $S \mu$ locus. There were no statistically significant differences between RA and control groups. There was no linkage disequilibrium between $\mathrm{S} \mu$ and $\mathrm{Gm}$ variants.

Similarly, Tables 3 and 4 show allele and phenotype frequencies at the S $\alpha 1$ locus. Once again there were no statistically significant differences between RA and control groups. Allele frequencies in controls were similar to those previously reported. ${ }^{11}$ Also as previously reported ${ }^{11}$ the $6.9 \mathrm{~kb}$ and $6.8 \mathrm{~kb}$ fragments were in linkage disequilibrium with $\mathrm{Gm}$ haplotypes zag and zaxg, while the $7.4 \mathrm{~kb}$ fragment was in linkage disequilibrium with $\mathrm{Gm}$ haplotypes $\mathrm{fb}$

Table 1 Allelic designations and frequencies for $S \mu$ in patients with rheumatoid arthritis and in controls (frequencies in parentheses)

\begin{tabular}{lcccc}
\hline & \multicolumn{4}{c}{ Molecular length $(\mathrm{kb})$ of Su alleles } \\
\cline { 2 - 5 } & $2 \cdot 7$ & $2 \cdot 2$ & $2 \cdot 6$ & $2 \cdot 75$ \\
\hline Controls $(\mathrm{n}=176)$ & 78 & 91 & 1 & 6 \\
& $(0 \cdot 44)$ & $(0 \cdot 52)$ & $(0 \cdot 005)$ & $(0 \cdot 03)$ \\
URAs* $(\mathrm{n}=252)$ & 123 & 118 & 2 & 9 \\
& $(0 \cdot 48)$ & $(0 \cdot 47)$ & $(0 \cdot 008)$ & $(0 \cdot 04)$ \\
DR4+ RA* $(\mathrm{n}=138)$ & 59 & 70 & 1 & 8 \\
& $(0 \cdot 43)$ & $(0 \cdot 50)$ & $(0 \cdot 007)$ & $(0 \cdot 06)$ \\
DR4- RA $(\mathrm{n}=82)$ & 45 & 36 & - & 1 \\
& $(0 \cdot 55)$ & $(0 \cdot 44)$ & - & $(0 \cdot 01)$ \\
\hline
\end{tabular}

${ }^{*}$ URAs represent pooled results for DR4+, DR4-, and nontissue-typed patients with rheumatoid arthritis; $R A=$ rheumatoid arthritis.

Differences were not statistically significant. and fnb as calculated from the formula of Mattiuz

There were no significant differences in $\mathrm{Gm}$ or A2m allotype frequencies between patients with $\mathrm{RA}$ overall and controls as reported previously. ${ }^{6}$ Thirty eight of the controls were DR4 positive and 77 DR negative. There were no significant differences iff $\operatorname{G1m}(\mathrm{x})$ or $\mathrm{A} 2 \mathrm{~m}(2)$ allotype frequencies betwee DR4 positive and negative control groups (G1m(xd) $0.16 v 0.25$ and $\mathrm{A} 2 \mathrm{~m}(2) 0.08 v 0.03$ in DR4 positive and DR4 negative subjects respectively). Controls were therefore pooled in the subsequent analysis The frequency of the allotype $\operatorname{Glm}(x)$ in DR positive RA was greater than in both DR4 negative RA and controls, though the differences comparec్ with the control group studied here were not statistio cally significant (Table 5). The frequency of the A $2 \mathrm{~m}(2)$ allotype was also increased in DR4 positive्छ RA, but here the differences were statistically signio ficant compared with both DR4 negative RA and overall control groups.

Table 3 Allelic designations and frequencies for $S \alpha 1$ in patients with rheumatoid arthritis and in controis (frequencies in parentheses)

\begin{tabular}{|c|c|c|c|c|c|}
\hline & \multicolumn{5}{|c|}{ Molecular lengths ( $k b)$ of $S \alpha l$ alleles } \\
\hline & $7 \cdot 4$ & $6 \cdot 9$ & $6 \cdot 8$ & $7 \cdot 1$ & $7 \cdot 0^{\circ}$ \\
\hline Controls $(n=168)$ & $\begin{array}{l}105 \\
(0.63)\end{array}$ & $\begin{array}{l}33 \\
(0 \cdot 20)\end{array}$ & $\begin{array}{l}26 \\
(0 \cdot 16)\end{array}$ & $\begin{array}{l}2 \\
(0 \cdot 01)\end{array}$ & $\begin{array}{l}2 \\
(0 \cdot 01)\end{array}$ \\
\hline URAs* $(n=252)$ & $\begin{array}{l}165 \\
(0 \cdot 66)\end{array}$ & $\begin{array}{l}47 \\
(0 \cdot 19)\end{array}$ & $\begin{array}{l}37 \\
(0 \cdot 15)\end{array}$ & $\begin{array}{l}1 \\
(0.004)\end{array}$ & $\begin{array}{l}2 \\
(0 \cdot 0\end{array}$ \\
\hline $\mathrm{DR}^{4}+\mathrm{RA}^{*}(\mathrm{n}=136)$ & 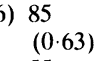 & $\begin{array}{l}28 \\
(0 \cdot 20)\end{array}$ & $\begin{array}{l}21 \\
(0 \cdot 15)\end{array}$ & - & $\begin{array}{l}2 \\
(0 \cdot 01\end{array}$ \\
\hline DR4-RA $(n=80)$ & $\begin{array}{l}55 \\
(0 \cdot 69)\end{array}$ & $\begin{array}{l}10 \\
(0 \cdot 13)\end{array}$ & $\begin{array}{l}14 \\
(0 \cdot 18)\end{array}$ & $\begin{array}{c}1 \\
(0 \cdot 01)\end{array}$ & - \\
\hline
\end{tabular}

*URAs represent pooled results for DR4+, DR4-, and non tissue-typed patients with rheumatoid arthritis; $\mathrm{RA}=$ rheumatoid arthritis.

Differences were not statistically significant.

Table 2 Phenotypic designations and frequencies for $S \mu$ in patients with rheumatoid arthritis and in controls (frequencie in parentheses)

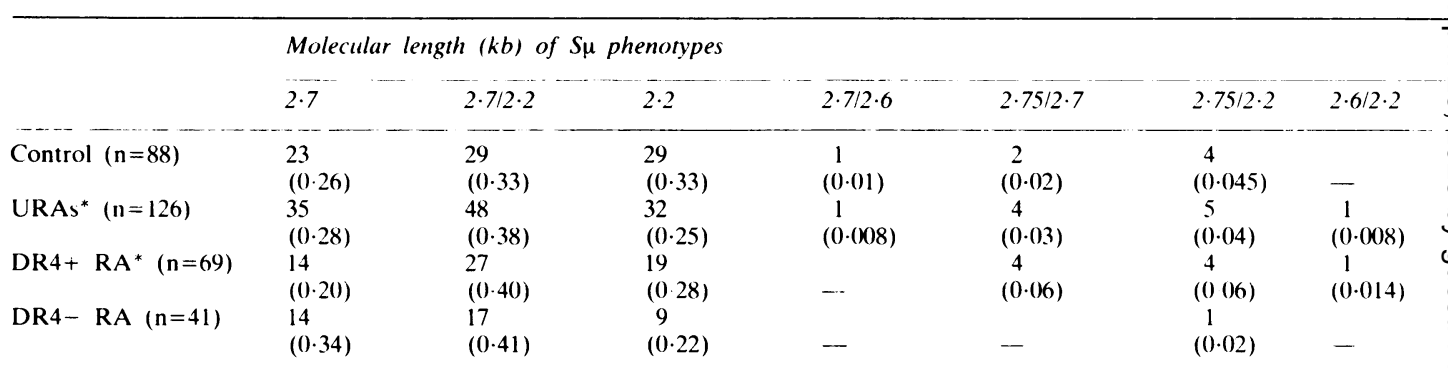

${ }^{*}$ URAs represent pooled results for DR4,$+ \mathrm{DR} 4-$, and non-tissue-typed patients with rheumatoid arthritis; $\mathrm{RA}=$ rheumatoid arthritis $\frac{\mathrm{O}}{\mathrm{D}}$ Differences were not statistically significant. 
Table 4 Phenotypic designations and freqeuncies with $S \alpha 1$ in patients with rheumatoid arthritis and in controls (frequencies in parentheses)

\begin{tabular}{|c|c|c|c|c|c|c|c|c|c|}
\hline & \multicolumn{9}{|c|}{ Molecular length $(k b)$ of $S \alpha l$ phenotypes } \\
\hline & $7 \cdot 4$ & $7 \cdot 4 / 6 \cdot 9$ & $7 \cdot 4 / 6 \cdot 8$ & $7 \cdot 4 / 7 \cdot 0$ & $7 \cdot 4 / 7 \cdot 1$ & 6.9 & $6 \cdot 8$ & $6 \cdot 9 / 6 \cdot 8$ & $7 \cdot 1 / 6 \cdot 9$ \\
\hline Controls $(n=84)$ & $\begin{array}{l}31 \\
(0 \cdot 37)\end{array}$ & $\begin{array}{l}20 \\
(0 \cdot 24)\end{array}$ & $\begin{array}{l}19 \\
(0 \cdot 23)\end{array}$ & $\begin{array}{l}2 \\
(0 \cdot 02)\end{array}$ & $\begin{array}{l}2 \\
(0 \cdot 02)\end{array}$ & $\begin{array}{l}6 \\
(0 \cdot 007)\end{array}$ & $\begin{array}{l}3 \\
(0 \cdot 035)\end{array}$ & $\begin{array}{l}1 \\
(0 \cdot 01)\end{array}$ & - \\
\hline URAs* $^{*}(n=126)$ & $\begin{array}{l}54 \\
(0 \cdot 43)\end{array}$ & $\begin{array}{l}27 \\
(0 \cdot 21)\end{array}$ & $\begin{array}{l}28 \\
(0 \cdot 22)\end{array}$ & $\begin{array}{l}2 \\
(0 \cdot 015)\end{array}$ & - & $\begin{array}{l}9 \\
(0 \cdot 07)\end{array}$ & $\begin{array}{l}4 \\
(0 \cdot 03)\end{array}$ & $\begin{array}{l}1 \\
(0 \cdot 007)\end{array}$ & $\begin{array}{l}1 \\
(0.007)\end{array}$ \\
\hline$D^{2} 4+R^{*}(n=68)$ & $\begin{array}{l}29 \\
(0 \cdot 43)\end{array}$ & $\begin{array}{l}13 \\
(0 \cdot 19)\end{array}$ & $\begin{array}{l}12 \\
(0 \cdot 18)\end{array}$ & $\begin{array}{l}2 \\
(0.03)\end{array}$ & - & $\begin{array}{c}7 \\
(0 \cdot 10)\end{array}$ & $\begin{array}{c}4 \\
(0 \cdot 06)\end{array}$ & $\begin{array}{l}1 \\
(0 \cdot 015)\end{array}$ & - \\
\hline DR4- RA $(n=40)$ & $\begin{array}{l}18 \\
(0 \cdot 45)\end{array}$ & $\begin{array}{l}5 \\
(0 \cdot 13)\end{array}$ & $\begin{array}{l}14 \\
(0 \cdot 35)\end{array}$ & - & - & $\begin{array}{l}2 \\
(0 \cdot 05)\end{array}$ & - & - & $\begin{array}{l}1 \\
(0 \cdot 025)\end{array}$ \\
\hline
\end{tabular}

*URAs represent pooled results for DR4+, DR4-, and non-tissue-typed patients with rheumatoid arthritis; RA=rheumatoid arthritis. Differences were not statistically significant.

Table 5 Immunoglobulin $\mathrm{Gm}$ and $A 2 m$ allotype frequencies in rheumatoid arthritis $(R A)$ and control groups (frequencies in parentheses)

\begin{tabular}{lllr}
\hline & $\begin{array}{l}D R 4 \text { positive } \\
R A(n=92)\end{array}$ & $\begin{array}{l}\text { DR4 negative } \\
R A(n=52)\end{array}$ & $\begin{array}{l}\text { Controls } \\
(n=115)\end{array}$ \\
\hline $\mathrm{G} 1 \mathrm{~m}(\mathrm{x})$ & $29(0 \cdot 32)^{*}$ & $5(0 \cdot 1)$ & $25(0 \cdot 22)$ \\
$\mathrm{A} 2 \mathrm{~m}(2)$ & $11(0 \cdot 12)^{\dagger}$ & $0(0)$ & $5(0 \cdot 04)$
\end{tabular}

${ }^{*} \mathrm{p}=0.003 v$ DR4 negative RA (Fisher's exact test).

tp$=0.006 v$ DR4 negative RA; $\mathrm{p}=0.038 v$ controls (Fisher's).

\section{Discussion}

The results of some previous studies based mainly on $\mathrm{Gm}$ allotyping ${ }^{5-7}$ and more recently on the study of DNA variants ${ }^{17}$ have suggested that genes linked to the immunoglobulin heavy chain constant region loci may have an effect on susceptibility to RA. We have attempted to examine this possibility further by studying polymorphisms at $S \mu$ and $S \alpha 1$ loci in parallel with a study of $\mathrm{Gm}$ and $\mathrm{A} 2 \mathrm{~m}$ allotypes. There is linkage disequilibrium between the $6.9 \mathrm{~kb}$ S $\alpha 1$ variant and $\mathrm{Gm}$ haplotypes zag and zaxg and between the $7.4 \mathrm{~kb} S \alpha 1$ fragment and Gm haplotypes fnb and fb. ${ }^{11}$ In our study there are no statistically significant differences in $\mathrm{S} \mu$ and $\mathrm{S} \alpha 1$ frequencies between RA, either DR4 positive or DR4 negative, and control groups. These results contrast with those of Sakkas and coworkers, ${ }^{18}$ who did not distinguish between $6.9 \mathrm{~kb}$ and $6.8 \mathrm{~kb} \mathrm{~S} \alpha \mathrm{l}$ fragments, but reported a decreased frequency of their ' $6.9 \mathrm{~kb}$ ' homozygotes in a group of London Europid subjects with RA. The main differences between the two studies lie in the control frequencies of ' $6.9 \mathrm{~kb}$ ' homozygotes with the London group reporting $19.1 \%$ in controls, whereas in our study the equivalent frequency is between $10 \%$ and $11 \%$ for both RA and control subjects (pooling $6.9 \mathrm{~kb}, 6.8 \mathrm{~kb}$, and
$6.8 \mathrm{~kb} / 6.9 \mathrm{~kb}$ phenotypes). It is possible in this study that with larger numbers some of the minor differences seen between patients with RA and controls may become statistically significant, but our results make it unlikely that genes closely linked to $\mu$ or $\alpha 1$ loci have any major effect on susceptibility to RA.

As previously reported the frequency of the $\mathrm{G} 1 \mathrm{~m}(\mathrm{x})$ allotype (gamma-1 locus) is greater in DR4 positive RA than in DR4 negative RA and controls, though with the numbers reported here the differences compared with controls fail to reach statistical significance. In this study, however, we report a stronger association between $\mathrm{RA}$ and the $\operatorname{IgA} 2$ allotype, A2m(2), which is found in linkage disequilibrium with Gm halotypes zaxg and zag. Both $\mathrm{G} 1 \mathrm{~m}(\mathrm{x})$ and $\mathrm{A} 2 \mathrm{~m}(2)$ are found in only a minority of subjects with RA, and these associations are likely to represent linkage disequilibrium with susceptibility gene(s) elsewhere in this region of chromosome 14 rather than any direct effect. These associations could represent linkage disequilibrium with variable region genes. There is evidence, however, for a recombination hotspot between variable and constant regions, ${ }^{19}$ so that the possibility of a direct contribution of genes within the heavy chain constant region on disease susceptibility cannot be discounted. In view of the association now described between RA and $\mathrm{A} 2 \mathrm{~m}(2)$ study of further variants closely linked to the $\alpha 2$ locus would be of interest.

We acknowledge with thanks financial support from the Wellcome Trust and from the Arthritis and Rheumatism Council. We are indebted to Professor Honjo for donating the H24 clone. HLA-DR typing was by courtesy of Dr P Dyer.

\footnotetext{
References

1 Lawrence J S. Rheumatoid arthritis. In: Rheumatism in populations. London: Heinemann, 1977: 156-271.

2 Grennan D M. Sanders P A, Dyer P A. Harris R. HLA haplo-
} 
type sharing by siblings with rheumatoid arthritis: evidence for genetic heterogeneity. Ann Rheum Dis 1986; 45: 126-9.

3 Walsh L J. Cox D W. Immunoglobulin (Gm) markers and $\alpha 1$ antitrypsin (PI) types in rheumatoid arthritis and early chronic active hepatitis. J Immunogenet 1984: 11: 115-20.

4 Archimandritis A. Kalos A. Papkonstantinou G. Babionitakis A. Theodoropoulos G. Dimitriadii P. The Gm and Am factors in rheumatoid arthritis. Acta Genet Med Gemellol (Roma) 1975: 24: $333-5$.

5 Propert D N, Kay P. McClusky J, Zilko P. Mathews J D. Immunoglobulin allotypes in rheumatoid arthritis. In: Dawkins A L, Christiansen F T, Zilko P J, eds. Immunogenetics of rheumatoid arthritis. Vol 3. Amsterdam: Excerpta Medica, 1983: 127-9.

6 Sanders P A. De Lange G G. Dyer P A. Grennan D M. Gm and $\mathrm{Km}$ allotypes in rheumatoid arthritis. Ann Rheum Dis 1985: 44: $529-32$.

7 Zarnowski H. Mierau R. Werdier O. Antony N. Garth E. Increased frequency of $\mathrm{Gm}$ (1.2.21) phenotype in HLA-DRt positive seropositive rheumatoid arthritis. $J$ Rheumatol 1986: 13: $858-63$.

8 Gran J T, Goodier P I, Husby G. Thorsby E. IgG heavy chain (Gm) allotypes in rheumatoid arthritis and in healthy individuals seropositive for IgM-rheumatoid factor. Scand $J$ Rheumatol 1985: 14: 144-8.

9 Collier D H. Kerwar S S. Brown R. Stobo J D. Schanfield R S. Immunoglobulin $\mathrm{G}$ heavy chain $(\mathrm{Gm})$ allotypes and the immune response to type I and II collagen in rheumatoid arthritis. Disease Markers 1985: 3: 91-102.

10 Sanders P A. Grennan D M. Klimiuk P S. et al. Gm allotypes and HLA in rheumatoid arthritis patients with circulating anti- bodies to native type II collagen. Am Rheum Dis 1987: 46: $\frac{\overline{5}}{3}$ 391-4.

11 Migone N. Leder J. Cann $H$. et al. Multiple DNA fragment $\bar{\omega}$ polymorphisms associated with immunoglobulin $\mu$ chain switch like regions in man. Proc Nat Acad Sci USA 1983: 80: 467-71. ज़

12 Ropes M W. Diagnostic criteria for rheumatoid arthritis. 1958 version. Ann Rheum Dis 1959; 18: 44-53.

13 Van Loghem E. Genetic studies on human immunoglobulins. In: Weir D M ed. Handbook of experimental immunology. 3rd ed. Oxford: Blackwell, 1978: 1-11, 16.

14 Maniatis T. Fritsch E F. Sambrook J. Molecular cloning: a laboratory manual. New York: Cold Spring Harbour Labora-e tory. 1982: 383-9.

15 Takahashi N. Nakai S. Honjo T. Clarity of human immunoglobulin $\mu$ gene and comparison with mouse $\mu$ gene. Nucleic Acids Res 1980: 8: 5983-91.

16 Feinberg A P. Vogelstein B. A technique for radiolabelling DNA restriction endonuclease fragments to high specific activity. Anal Biochem 1983: 132: 6-13.

17 Mattiuz P L. Ihda D. Piazza A. Ceppellini R. Bodmer W. New approaches to the population genetic and segregation analysis $\vec{O}$ of the HLA system. In: Histocompatibility testing. Copenhagen: Munksgaard. 1970: 193-205.

18 Sakkas L I. Demaine A G. Vaughan R W. Welsh K I. Panayi $\mathrm{GS}$. The association of DNA fragments at or near the IgH locus with rheumatoid arthritis $J$ lmmunogenet 1987: 14: 189-96.

19 Purrello M. Alhadeff B. Whittingham E. et al. Comparison of

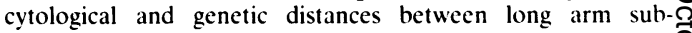
telomeric markers of human autosome 14 suggests uneven음 distribution of crossing over. Cytogenet Cell Genet 1987: 44: $32-40$. 